\title{
Anoxic conditions maintained high phosphorus sorption in humid tropical forest soils
}

\author{
Yang Lin ${ }^{1}$, Avner Gross ${ }^{1, a}$, Christine S. O'Connell ${ }^{1}$, and Whendee L. Silver ${ }^{1}$ \\ ${ }^{1}$ Department of Environmental Science, Policy, and Management, University of California, Berkeley, CA 94720, USA \\ ${ }^{a}$ current address: Department of Geography and Environmental Development, Ben-Gurion University of the Negev, \\ Beersheba, Israel
}

Correspondence: Yang Lin (yanglin@ berkeley.edu)

Received: 22 February 2019 - Discussion started: 26 February 2019

Revised: 7 September 2019 - Accepted: 11 November 2019 - Published: 7 January 2020

\begin{abstract}
The strong phosphorus $(\mathrm{P})$ sorption capacity of iron $(\mathrm{Fe})$ and aluminum (Al) minerals in highly weathered, acidic soils of humid tropical forests is generally assumed to be an important driver of $\mathrm{P}$ limitation to plants and microbial activity in these ecosystems. Humid tropical forest soils often experience fluctuating redox conditions that reduce $\mathrm{Fe}$ and raise $\mathrm{pH}$. It is commonly thought that $\mathrm{Fe}$ reduction generally decreases the capacity and strength of $\mathrm{P}$ sorption. Here we examined the effects of $14 \mathrm{~d}$ oxic and anoxic incubations on soil $\mathrm{P}$ sorption dynamics in humid tropical forest soils from Puerto Rico. Contrary to the conventional belief, soil $\mathrm{P}$ sorption capacity did not decrease under anoxic conditions, suggesting that soil minerals remain strong $P$ sinks even under reducing conditions. Sorption of $\mathrm{P}$ occurred very rapidly in these soils, with at least $60 \%$ of the added $\mathrm{P}$ disappearing from the solution within $6 \mathrm{~h}$. Estimated P sorption capacities were much higher, often by an order of magnitude, than the soil total P contents. However, the strength of P sorption under reducing conditions was weaker, as indicated by the increased solubility of sorbed $\mathrm{P}$ in $\mathrm{NaHCO}_{3}$ solution. Our results show that highly weathered soil minerals can retain $\mathrm{P}$ even under anoxic conditions, where it might otherwise be susceptible to leaching. Anoxic events can also potentially increase $\mathrm{P}$ bioavailability by decreasing the strength, rather than the capacity, of $\mathrm{P}$ sorption. These results improve our understanding of the redox effects on biogeochemical cycling in tropical forests.
\end{abstract}

\section{Introduction}

Phosphorus $(\mathrm{P})$ is often thought to limit net primary productivity and organic-matter decomposition in humid tropical forests that grow on strongly weathered soils (Vitousek and Sanford Jr., 1986; Cleveland et al., 2011; Camenzind et al., 2017). In these soils, geochemical reactions of adsorption and precipitation, also known as sorption, directly compete with plant roots and microorganisms for phosphate (Thompson and Goyne, 2012). Sorption reactions can immobilize a large amount of $\mathrm{P}$ that can exceed the actual size of the labile soil $\mathrm{P}$ pools (de Campos et al., 2016; Roy et al., 2017; Gross et al., 2018) at the scales of seconds to hours (Olander and Vitousek, 2004; McGechan and Lewis, 2002). The sorbed P is generally not readily available for plant and microbial uptake (Tiessen and Moir, 1993). Thus, mineral sorption plays a key role in constraining the biological availability of $\mathrm{P}$ in these ecosystems (Johnson et al., 2003; Reed and Wood, 2016).

How do plants and microbes acquire $\mathrm{P}$ in tropical forest soils with high P sorption potential? One of the commonly hypothesized, yet rarely tested, mechanisms is that reducing events can decrease the effectiveness of soil minerals in sorbing P (Chacón et al., 2006; Lin et al., 2018). These soils often contain high concentrations of redox-sensitive poorly crystalline or amorphous Fe minerals (Hall and Silver, 2015; Wilmoth et al., 2018; de Campos et al., 2016). Under anoxic conditions, Fe(III) minerals undergo reductive dissolution and are transformed into $\mathrm{Fe}$ (II) phases that are assumed to be less effective at binding P (Quintero et al., 2007; Rakotoson et al., 2014; Shenker et al., 2005). Reducing conditions increase $\mathrm{pH}$ and decrease surface charges that are thought to 
be central to P sorption (Oh et al., 1999; Willett, 1989). Although Al minerals, which are often enriched in these soils, are not redox-active, redox-induced $\mathrm{pH}$ changes can control the speciation of $\mathrm{Al}$ minerals and consequently affect $\mathrm{P}$ sorption (Haynes, 1982; Gustafsson et al., 2012).

Redox effects on soil P sorption processes have not been well studied in tropical forest soils even though periodic redox oscillations are well documented in these environments (Barcellos et al., 2018; Schuur et al., 2001; Chen et al., 2018; Keiluweit et al., 2016; Wieder et al., 2011; O'Connell et al., 2018; Silver et al., 1999). Some past studies from tropical ecosystems have reported increases in extractable soil P during anoxic events (Chacón et al., 2006; Peretyazhko and Sposito, 2005; Maranguit et al., 2017), which is consistent with the hypothesis that anoxic conditions weaken $\mathrm{P}$ sorption, although the mechanisms remain unclear. To better understand the importance of redox events in regulating $\mathrm{P}$ bioavailability in tropical forest soils, it is necessary to examine both the capacity and strength of P sorption. Sorption capacity is usually characterized by the maximum amount of $P$ that soil minerals can sorb and can be measured using the sorption isotherm method (McGechan and Lewis, 2002). The strength of $\mathrm{P}$ sorption is related to the potential bioavailability of the sorbed $\mathrm{P}$, as strongly sorbed $\mathrm{P}$ is considered to be largely unavailable to plant roots and microbes. This can be evaluated by measuring the solubility of sorbed $\mathrm{P}$ in various extracting solutions such as $\mathrm{NaHCO}_{3}$ and $\mathrm{NaOH}$ (Ryden and Syers, 1977).

We determined the effects of redox conditions (oxic vs. anoxic incubations) on P sorption characteristics in soils from humid tropical forests in Puerto Rico. We conducted two types of P sorption experiments: (1) the standard sorption isotherm to evaluate the capacity of $\mathrm{P}$ sorption and (2) the $\mathrm{P}$ sorption time curve to evaluate the rate of $\mathrm{P}$ sorption over time. These $\mathrm{P}$ sorption experiments were conducted using soils from two distinct parent materials with different $\mathrm{Fe}$, $\mathrm{Al}$, and $\mathrm{P}$ concentrations and two topographic positions (frequently reduced valleys and more aerated slopes), allowing us to evaluate the effects of soil redox history on P sorption processes. We also measured the relative solubility of sorbed $\mathrm{P}$ in $\mathrm{NaHCO}_{3}$ and $\mathrm{NaOH}$ solution to evaluate the strength of $\mathrm{P}$ sorption. We hypothesized that anoxic conditions would decrease soil $\mathrm{P}$ sorption capacity due to a decrease in $\mathrm{Fe}$ (III) concentrations and associated weakening of the $\mathrm{Fe}-\mathrm{P}$ bond. We also hypothesized that redox-induced decreases in $\mathrm{P}$ sorption capacity would be accompanied by increases in the solubility of sorbed $\mathrm{P}$, indicative of weaker $\mathrm{P}$ sorption strength.

\section{Material and methods}

\subsection{Study sites and soil sampling}

Soils were collected from humid tropical forests in the Luquillo Experimental Forest (LEF) in Puerto Rico, part of the NSF-sponsored Long Term Ecological Research (LTER) and Critical Zone Observatory (CZO) networks and the DOE-sponsored NGEE-Tropics program. The mean annual temperature decreased from about $23^{\circ} \mathrm{C}$ at $350 \mathrm{~m}$ a.s.l to about $19^{\circ} \mathrm{C}$ at $930 \mathrm{~m}$ a.s.l (Weaver and Murphy, 1990; Brown et al., 1983). Mean annual rainfall increased from about $3200 \mathrm{~mm}$ at $300 \mathrm{~m}$ a.s. 1 to about $4800 \mathrm{~mm}$ at $1000 \mathrm{~m}$ a.s.l, with no clear seasonal pattern (Murphy et al., 2017). Mineral soils $(0-15 \mathrm{~cm}$ depth) were collected from two sites, El Verde and Rio Icacos, featuring different parent materials and soil characteristics (Table 1). The El Verde site is located at approximately $380 \mathrm{~m}$ a.s.l within the tabonuco forest zone. The Rio Icacos site is located at approximately $630 \mathrm{~m}$ within the Colorado forest zone and characterized by more frequent cloud condensation and abundant epiphytes. Soils from El Verde were Hapludoxes and derived from volcaniclastic material (Scatena, 1989). Soils from Rio Icacos were Dystrudepts and developed from quartz diorite material, which contained approximately half as much total $\mathrm{P}$ compared to volcaniclastic material and lower concentrations of $\mathrm{Fe}$ and $\mathrm{Al}$ oxides (Mage and Porder, 2012). As a result, soils from El Verde generally have higher total concentrations of $\mathrm{P}, \mathrm{Fe}$, and $\mathrm{Al}$ minerals (Mage and Porder, 2012; Coward et al., 2017). Topographic location (ridge, slope, and valley) plays a key role in determining soil redox conditions and biogeochemical processes (Scatena, 1989; Silver et al., 1994; O'Connell et al., 2018; Hall and Silver, 2015). In these highly dissected landscapes, catenas typically vary from well-aerated ridges to valley bottoms that experience frequent reducing events. Slopes cover approximately $65 \%$ of the landscape, while ridges and valleys make up the rest in approximately equal proportions (Scatena and Lugo, 1995). For the sorption experiments, soils from both sites were collected from valley and slope positions after removing the surface litter layer. For the solubility experiment, we only analyzed the slope and valley soils from the El Verde site due to logistical limitations in accessing the Rio Icacos site after Hurricane Maria. The valley soil sampled for the solubility experiment was significantly drier than that sampled previously (Table 1). Soils were shipped overnight to the University of California, Berkeley, at an ambient temperature and were immediately gently homogenized by hand upon arrival, and visible plant debris, rocks, and macro-fauna were removed.

\subsection{Redox treatments}

To examine the effects of low-redox conditions on soil $\mathrm{P}$ sorption processes, soil samples were pre-incubated under 
Table 1. Initial soil characteristics ( $n=4$ per sampling location).

\begin{tabular}{llrrrrrrrr}
\hline Site & Position & $\begin{array}{r}\text { Gravimetric soil } \\
\text { moisture (\%) }\end{array}$ & pH & $\begin{array}{r}\text { Total soil C } \\
(\%)\end{array}$ & $\begin{array}{r}\text { Total soil N } \\
(\%)\end{array}$ & $\begin{array}{r}\mathrm{HCl}-\mathrm{Fe}(\mathrm{II}) \\
\left(\mathrm{g} \mathrm{Fe} \mathrm{kg}^{-1}\right)\end{array}$ & $\begin{array}{r}\mathrm{HCl}-\mathrm{Fe}(\mathrm{III}) \\
\left(\mathrm{g} \mathrm{Fe} \mathrm{kg}^{-1}\right)\end{array}$ & $\begin{array}{r}\mathrm{AO}-\mathrm{Fe} \\
\left(\mathrm{g} \mathrm{Fe} \mathrm{kg}^{-1}\right)\end{array}$ & $\begin{array}{r}\mathrm{AO}-\mathrm{Al} \\
\left(\mathrm{g} \mathrm{Al} \mathrm{kg}^{-1}\right)\end{array}$ \\
\hline \multirow{2}{*}{ El Verde 1 } & Slope & $95.7 \pm 2.4$ & $5.27 \pm 0.02$ & $7.06 \pm 0.37$ & $0.386 \pm 0.007$ & $0.054 \pm 0.002$ & $1.97 \pm 0.11$ & $0.84 \pm 0.15$ & $0.37 \pm 0.04$ \\
& Valley & $124.5 \pm 1.3$ & $5.70 \pm 0.06$ & $5.91 \pm 0.16$ & $0.307 \pm 0.004$ & $9.42 \pm 0.29$ & $1.94 \pm 0.05$ & $4.65 \pm 0.72$ & $0.45 \pm 0.07$ \\
\hline \multirow{2}{*}{ Rio Icacos } & Slope & $71.6 \pm 0.4$ & $4.72 \pm 0.01$ & $3.90 \pm 0.06$ & $0.196 \pm 0.002$ & $0.14 \pm 0.04$ & $0.84 \pm 0.13$ & $0.35 \pm 0.04$ & $1.18 \pm 0.07$ \\
& Valley & $103.7 \pm 0.3$ & $5.26 \pm 0.06$ & $4.28 \pm 0.11$ & $0.237 \pm 0.002$ & $0.14 \pm 0.01$ & $0.82 \pm 0.04$ & $0.37 \pm 0.02$ & $2.13 \pm 0.12$ \\
\hline El Verde 2 & Slope & $85.1 \pm 2.4$ & n.d. & n.d. & n.d. & n.d. & n.d. & n.d. & n.d. \\
P solubility & Valley & $78.5 \pm 0.4$ & n.d. & n.d. & n.d. & n.d. & n.d. & n.d. \\
\hline
\end{tabular}

Means and SE are shown. n.d.: not determined.

anoxic or oxic conditions for $14 \mathrm{~d}$. Soils were subsampled in quart-size glass jars with gas-tight lids $(\sim 100 \mathrm{~g}$ each; oven-dry equivalent - ODE). For those in the anoxic treatment, the jar headspace was evacuated and flushed with $\mathrm{N}_{2}$ three times before being transferred to an anaerobic glovebox $\left(90 \% \mathrm{~N}_{2}, 8 \% \mathrm{CO}_{2}\right.$, and $2 \% \mathrm{H}_{2}$; Coy Laboratory Products, Grass Lake, MI). Jars were sealed inside the glovebox and vented every 2 or $3 \mathrm{~d}$. Jars in the oxic treatment were sealed under an ambient atmosphere and vented following the same schedule as those from the anoxic treatment. Jars were stored in cardboard boxes in the dark during the incubation. Soils from El Verde and Rio Icacos were analyzed in two separate campaigns following the same experimental approach due to space limitations in the glovebox.

\subsection{Phosphorus sorption experiments}

After pre-incubation, soil $\mathrm{P}$ sorption was evaluated in two ways. We used $\mathrm{P}$ sorption isotherm experiments to determine sorption across a range of standard $\mathrm{P}$ loadings over $24 \mathrm{~h}$. We also conducted P sorption time curves that characterize the disappearance of solution $\mathrm{P}$, with one level $\mathrm{P}$ of addition at multiple time points over $48 \mathrm{~h}$ (Henry and Smith, 2006). For P sorption isotherms, aliquots of $15 \mathrm{~g}$ of ODE soil were subsampled into pint-size glass jars containing $150 \mathrm{~mL}$ of $0.01 \mathrm{M} \mathrm{CaCl}_{2}$ to reach a soil-to-solution ratio of $1: 10$. The $\mathrm{CaCl}_{2}$ solution had been previously spiked with $100 \mathrm{mg} \mathrm{PL}^{-1} \mathrm{KH}_{2} \mathrm{PO}_{4}$ stock solution to reach four levels of $\mathrm{P}$ concentrations $\left(500,1000,5000\right.$, and $10000 \mathrm{mg} \mathrm{Pkg}^{-1}$ of soil). Preliminary trials showed that $\mathrm{P}$ addition at lower concentrations (i.e., 10 and $100 \mathrm{mg} \mathrm{Pg}^{-1}$ of soil) resulted in near-complete sorption within $24 \mathrm{~h}$ (Fig. S1 in the Supplement), and many samples had no detectable $\mathrm{P}$ in solution. The estimated maximum sorption capacity was extremely close to the highest $\mathrm{P}$ addition level (i.e., $1000 \mathrm{mg} \mathrm{Pkg}^{-1}$ of soil) used in traditional sorption studies (Roy et al., 2017; Wisawapipat et al., 2009; Gustafsson et al., 2012; Borggaard et al., 1990). Thus, here we used higher levels of $\mathrm{P}$ concentrations, including 5000 and $10000 \mathrm{mg} \mathrm{Pkg}^{-1}$ of soil. Similar levels of $\mathrm{P}$ addition have been previously used (de Campos et al., 2016; Zhang et al., 2003). There was a total of 128 samples ( 4 replicates $\times 4$ levels of $\mathrm{P}$ addition $\times 2$ re- dox treatments $\times 2$ topographic locations $\times 2$ sample sites). Soil slurry was then amended with $1 \mathrm{~mL}$ of toluene to inhibit microbial activity before being manually shaken for $1 \mathrm{~min}$. Samples from the anoxic treatment were prepared in the anoxic glovebox with degassed solutions. The slurry was manually shaken periodically to mix soils with solution. After $24 \mathrm{~h}, 5 \mathrm{~mL}$ subsamples of soil slurry were extracted from each jar and filtered through $0.45 \mu \mathrm{m}$ syringe filters into test tubes and then acidified with $\mathrm{HCl}$ to a final $\mathrm{H}^{+}$concentration of $0.1 \mathrm{~N}$ to prevent the oxidation and precipitation of dissolved $\mathrm{Fe}(\mathrm{II})$.

For P sorption time curves, batch experiments were started by subsampling aliquots of $30 \mathrm{~g}$ of soil (ODE) into quart-size glass jars with $300 \mathrm{~mL}$ of $0.01 \mathrm{M} \mathrm{CaCl}_{2}$ solution with a single pulse of $1000 \mathrm{mg} \mathrm{Rg}^{-1}$ of soil and $2 \mathrm{~mL}$ of of toluene. A total of 32 samples ( 4 replicates $\times 2$ redox treatments $\times 2$ topographic locations $\times 2$ sample sites) were prepared. Subsamples of suspended soil were taken after $5 \mathrm{~min}, 40 \mathrm{~min}, 2 \mathrm{~h}$, $6 \mathrm{~h}, 12 \mathrm{~h}, 24 \mathrm{~h}$, and $48 \mathrm{~h}$ following the previously described method. Solution P concentrations from the sorption experiments were determined colorimetrically, following Murphy and Riley (1962).

\subsection{Soil $\mathrm{Fe}$ and $\mathrm{Al}$ analyses and $\mathrm{P}$ fractions}

Redox-active $\mathrm{Fe}$ pools were measured after the preincubation. Acid-soluble $\mathrm{Fe}$ was extracted by mixing $4 \mathrm{~g}$ of ODE soil in $40 \mathrm{~mL}$ of $0.5 \mathrm{M}$ hydrochloric acid $(\mathrm{HCl})$ solution and shaking for $1 \mathrm{~h}$, followed by centrifugation. The $\mathrm{HCl}-$ extractable $\mathrm{Fe}$ (II) and $\mathrm{Fe}$ (III) (HCl-Fe(II) and $\mathrm{HCl}-\mathrm{Fe}(\mathrm{III})$ ) concentrations were determined using a modified ferrozine assay (Viollier et al., 2000). Ammonium oxalate (AO) solution was used to estimate the concentrations of poorly crystalline $\mathrm{Fe}$ and $\mathrm{Al}$ minerals. A pre-treatment with $0.1 \mathrm{M} \mathrm{HCl}$ was used to remove $\mathrm{Fe}$ (II) before the $\mathrm{AO}$ extraction to avoid catalytic dissolution of crystalline Fe minerals in the presence of $\mathrm{Fe}(\mathrm{II})$ and oxalate at reducing conditions (Heiberg et al., 2012). Aliquots of $1 \mathrm{~g}$ of ODE soil were mixed with $10 \mathrm{~mL}$ of $0.1 \mathrm{M} \mathrm{HCl}$ for $10 \mathrm{~min}$ on an end-to-end shaker, followed by centrifugation. Samples were then washed with $40 \mathrm{~mL}$ of $\mathrm{H}_{2} \mathrm{O}$, centrifuged, and subsequently used for $\mathrm{AO}$ extraction $(40 \mathrm{~mL})$ at a $\mathrm{pH}$ of 3.0 in the dark for $2 \mathrm{~h}$. The $\mathrm{AO}$ 
extract was then filtered through a $0.45 \mu \mathrm{m}$ syringe filter before determination of $\mathrm{Fe}$ and $\mathrm{Al}$ concentrations (AO-Fe and AO-Al) with inductively coupled plasma optical emission spectrometry (ICP-OES) on three analytical replicates per sample (PerkinElmer, Optima 5300 DV series, CA, USA).

Soil $\mathrm{P}$ fractions were estimated using a modified Hedley scheme after the pre-incubation and before the sorption test (Hedley et al., 1982). Aliquots of $1 \mathrm{~g}$ of ODE soil were sequentially extracted using $40 \mathrm{~mL}$ of $0.5 \mathrm{M}$ sodium bicarbonate $\left(\mathrm{NaHCO}_{3}\right)$ and $0.1 \mathrm{M}$ sodium hydroxide $(\mathrm{NaOH})$ solution, each for $16 \mathrm{~h}$. The $\mathrm{NaHCO}_{3}$ solution extracts inorganic and organic $\mathrm{P}$ that are weakly associated to soil particles and commonly assumed to be biologically available (Tiessen and Moir, 1993). The $\mathrm{NaOH}$ solution mobilizes $\mathrm{P}$ compounds that are more strongly bound to $\mathrm{Fe}$ and $\mathrm{Al}$ minerals than those extracted by $\mathrm{NaHCO}_{3}$ solution, thus having intermediate availability (Tiessen and Moir, 1993). The total P concentration of both solutions was determined following Murphy and Riley (1962) after autoclaving the solution with ammonium persulfate $\left(\left(\mathrm{NH}_{4}\right)_{2} \mathrm{~S}_{2} \mathrm{O}_{8}\right)$.

\subsection{Phosphorus solubility experiments}

We assessed the strength of $\mathrm{P}$ sorption by measuring the relative solubility of $\mathrm{P}$ for the slope and valley at the El Verde site. Overall, there were 96 samples ( 4 replicates $\times 2$ extractants $\times 3$ levels of $\mathrm{P}$ addition $\times 2$ redox condition $\times 2$ soil types). Approximately $10 \mathrm{~g}$ of ODE soil was weighed into pint-size glass jars and incubated either under ambient air or in an anaerobic glovebox for $14 \mathrm{~d}$, following the method above. Samples then received $100 \mathrm{~mL}$ of $0.01 \mathrm{M} \mathrm{CaCl}_{2}$ solution containing 0,100 , or $1000 \mathrm{mg} \mathrm{Pkg}^{-1}$ of soil and $1 \mathrm{~mL}$ of toluene. Jars were capped and shaken for $24 \mathrm{~h}$ after which $5 \mathrm{~mL}$ subsamples of soil slurry were taken to estimate the amount of $\mathrm{P}$ remaining in solution and $\mathrm{P}$ sorbed by minerals using the methods described above. Microcosms then received $300 \mathrm{~mL}$ of either $0.667 \mathrm{M}$ of $\mathrm{NaHCO}_{3}$ or $0.133 \mathrm{M}$ of $\mathrm{NaOH}$ solution to reach the final concentrations of $0.5 \mathrm{M}$ of $\mathrm{NaHCO}_{3}$ and $0.1 \mathrm{M}$ of $\mathrm{NaOH}$, respectively. The two extracting solutions were used because they have different $\mathrm{P}$ extraction efficiencies. Solutions were shaken every $3 \mathrm{~h}$, including at both the beginning and the end of a $16 \mathrm{~h}$ overnight period prior to extraction. The anoxic treatment was conducted in the anoxic glovebox with degassed solutions. Determination of $\mathrm{NaHCO}_{3}$ and $\mathrm{NaOH}$ total $\mathrm{P}$ concentrations $\left(\mathrm{NaHCO}_{3}-\mathrm{P}_{\mathrm{t}}\right.$ and $\mathrm{NaOH}-\mathrm{P}_{\mathrm{t}}$, respectively) followed the previously described methods. The extracted $\mathrm{P}$ came from two potential sources: the $\mathrm{P}$ amendment (for the two treatments with $\mathrm{P}$ added) and native extractable $\mathrm{P}$. We accounted for the native extractable soil $\mathrm{P}$ in the treatment without $\mathrm{P}$ addition. We also accounted for the amendment $\mathrm{P}$ remaining in solution in order to estimate the amount of sorbed $\mathrm{P}$ recovered during extraction. The recovered $\mathrm{P}$ was then reported as a percentage of the sorbed $\mathrm{P}$ or the relative $\mathrm{P}$ solubility.

\subsection{Data analyses}

Sorption isotherm data were modeled using the Langmuir equation as in Eq. (1):

$S=\frac{a S_{\max } C}{1+a C}$,

in which $S$ is the amount of $\mathrm{P}$ sorbed during the batch experiment ( $\mathrm{mg} \mathrm{P} \mathrm{kg}^{-1}$ of soil), $S_{\max }$ corresponds to a predicted maximum sorption capacity ( $\mathrm{mg} \mathrm{P} \mathrm{kg}^{-1}$ of soil), $C$ is the concentration of $\mathrm{P}$ remaining in solution $\left(\mathrm{mg} \mathrm{PL}^{-1}\right)$, and $a$ represents a coefficient related to the bonding strength of $\mathrm{P}$ to soil minerals ( $\mathrm{L} \mathrm{mg}^{-1}$ of $\mathrm{P}$ ). For each combination of soil type and redox treatment, all data points were used to fit the Langmuir equation following the approach described by Bolster and Hornberger (2007). This approach estimated the means and standard errors of all model parameters, including $S_{\max }$. The goodness of fit was evaluated by model efficiency $(E)$, where $E=1$ indicates a perfect fit to the data.

It is possible that vivianite precipitation contributed to $\mathrm{P}$ sorption in the anoxic treatments, especially at high levels of $\mathrm{P}$ addition (5000 and $10000 \mathrm{mg} \mathrm{Pkg}^{-1}$ ), when $\mathrm{Fe}(\mathrm{II})$ concentrations were also high (Borch and Fendorf, 2007; Heiberg et al., 2012). The saturation index of vivianite was calculated using Visual MINTEQ, version 3.1 (Gustafsson, 2015). Model inputs included solution of $\mathrm{pH}$ and concentrations of inorganic $\mathrm{P}$ and $\mathrm{Fe}$ (II) in solution. We assumed that $10 \%$ of $\mathrm{HCl}-\mathrm{Fe}(\mathrm{II})$ was soluble in solution based on past studies using similar soils from Puerto Rico (Peretyazhko and Sposito, 2005; Wilmoth et al., 2018).

We also calculated a P sorption index (PSI; $\mathrm{L} \mathrm{kg}^{-1}$ of soil; Bache and Williams, 1971) using the sorption isotherm results under all four $\mathrm{P}$ addition levels in Eq. (2):

$\mathrm{PSI}=\frac{S}{\log _{10} C}$,

in which $S$ is the amount of $\mathrm{P}$ sorbed during the batch experiment ( $\mathrm{mg} \mathrm{P} \mathrm{kg}^{-1}$ of soil), and $C$ corresponds to the concentration of $\mathrm{P}$ remaining in solution $\left(\mathrm{mg} \mathrm{PL}^{-1}\right)$. High PSI values correspond to high $\mathrm{P}$ sorption capacity. Our discussion was focused on PSI values calculated at $1000 \mathrm{mg} \mathrm{P} \mathrm{kg}^{-1}$ because this level of $\mathrm{P}$ addition was similar to the one used by Bache and Williams $\left(1971 ; 1500 \mathrm{mg} \mathrm{Pkg}^{-1}\right)$ and facilitated comparison with $\mathrm{P}$ sorption time curves measured at the same $\mathrm{P}$ addition level.

Data from $\mathrm{P}$ sorption time curves were modeled using a power function as in Eq. (3):

$100-p=a t^{-k}$,

in which $p$ represents the percentage of $\mathrm{P}$ sorbed (\%), $t$ indicates time (h), $k$ corresponds to the rate of $\mathrm{P}$ sorption, and $a$ is a coefficient $\left(\mathrm{h}^{-1}\right)$. Higher values of $k$ indicate faster $\mathrm{P}$ sorption. Model fitting was conducted using the "nls" function in $\mathrm{R}$ version 3.4.4 (R Core Team, 2019). Effects of redox 
manipulation on PSI values and P solubility were compared using student's $t$ tests in each soil type at the $\alpha=0.05$ level. All analyses were conducted in R.

\section{Results}

\subsection{Redox effects on Fe, Al, and P sorption}

In all four types of soils, the anoxic treatment had significantly higher $\mathrm{HCl}-\mathrm{Fe}(\mathrm{II})$ concentrations relative to the oxic treatment (up to 2 orders of magnitude greater), providing evidence that soils experienced reducing conditions (Table 2). This effect was particularly strong in the slope soil at El Verde and at Rio Icacos (both $P<0.001$ ). Anoxic conditions decreased soil $\mathrm{HCl}-\mathrm{Fe}(\mathrm{III})$ concentrations relative to oxic conditions in the slope $(P<0.01)$ and valley $(P<$ $0.001)$ soil at El Verde. However, soil HCl-Fe(III) concentrations did not respond significantly to redox treatments in soils from Rio Icacos. Soil HCl-Fe(III) concentrations were significantly higher at El Verde than at Rio Icacos $(P<0.001$; Table 2).

Anoxic conditions decreased $\mathrm{AO}-\mathrm{Fe}$ concentrations in the valley soils from Rio Icacos $(P<0.001)$ and increased concentrations of AO-Al in the valley soil at El Verde $(P<0.05$; Table 2). However, effects of redox on AO-Fe and AO-Al concentrations were relatively small compared to their differences across sampling sites and topographic positions. Soils at El Verde had higher AO-Fe concentrations $(P<0.001)$ and lower AO-Al concentrations $(P<0.001)$ than those at Rio Icacos. Within the El Verde samples, the valley soil had higher AO-Fe concentrations $(P<0.01)$ and lower AO-Al concentrations $(P<0.001)$ than the slope soil. Within the Rio Icacos site, the valley soil had nearly doubled the $\mathrm{AO}-\mathrm{Al}$ concentrations compared to the slope soil $(P<0.001)$, while the two topographic zones had similar levels of AO-Fe.

Sorption isotherms of all soils generally followed the Langmuir functions (Fig. 1), as $E$ varied between 0.781 and 0.967 with an average of 0.898 (Table S1 in the Supplement). Estimated maximum sorption capacities ranged from $2627 \pm 303$ to $8256 \pm 2519 \mathrm{mg} \mathrm{P} \mathrm{kg}^{-1}$ (Table 2; mean \pm SE unless otherwise noted), which was 1 order of magnitude higher than total soil P concentrations (140-400 $\mathrm{mg} \mathrm{Pg}^{-1}$; Mage and Porder, 2012). Effects of redox treatments on P remaining in solution and the $\mathrm{P}$ sorbed differed among levels of $\mathrm{P}$ addition. Under high $\mathrm{P}$ additions (5000-10000 $\mathrm{mg} \mathrm{P} \mathrm{kg}^{-1}$ ), $P$ sorption (vertical axis in Fig. 1) was generally greater under the anoxic treatment with lower concentrations of $\mathrm{P}$ remaining in solution relative to the oxic treatment (horizontal axis in Fig. 1; Table S1). When $1000 \mathrm{mg} \mathrm{Pkg}^{-1}$ was added, there was significantly lower $\mathrm{P}$ remaining in solution under anoxic conditions at both slope soils $(P<0.01$ at El Verde and $P<0.001$ at Rio Icacos) and the valley soils at Rio Ica$\cos (P<0.01)$. Only the valley soils at El Verde showed significantly more $\mathrm{P}$ remaining in solution under anoxic con- ditions $(P<0.01)$. Similar trends were also observed at the lowest level of $\mathrm{P}$ addition $\left(500 \mathrm{mg} \mathrm{Pkg}^{-1}\right)$ : there was significantly less $P$ remaining in solution for the two slope soils under anoxic conditions $(P<0.01$ at El Verde and $P<0.001$ at Rio Icacos), and the opposite was true for the valley soils at El Verde $(P<0.01)$. The valley soils at Rio Icacos showed no significant differences in solution $P$ remaining between the two redox treatments at the $\mathrm{P}$ addition level of $500 \mathrm{mg} \mathrm{Pkg}^{-1}$.

The PSI values offered another way to examine the redox treatments on $\mathrm{P}$ sorption. Under high $\mathrm{P}$ additions (5000-10 $000 \mathrm{mg} \mathrm{Pg}^{-1}$ ), anoxic conditions led to PSI values greater than or similar to oxic conditions (Table S2). When $500 \mathrm{mg} \mathrm{kg}^{-1}$ was added, PSI values became negative in two valley soils under oxic conditions because their average $\mathrm{P}$ concentrations remaining in solution were lower than $1 \mathrm{mgL}^{-1}$, resulting in negative logarithms. Under $\mathrm{P}$ addition of $1000 \mathrm{mg} \mathrm{kg}^{-1}$, anoxic conditions led to lower PSI values than oxic conditions in the El Verde valley soil $(P<0.05$; Fig. 2$)$, while redox incubations did not significantly affect PSI in the valley soil from Rio Icacos. In contrast, anoxic conditions increased PSI values relative to the oxic treatment in the two slope soils (both $P<0.01$ ). The valley soils had $116 \pm 25 \%$ and $64 \pm 14 \%$ higher PSI values than the slope soils at El Verde and Rio Icacos, respectively (both $P<0.05$ ). Averaging between topographic positions, differences in PSI between the two sites were relatively small (El Verde vs. Rio Icacos: $720 \pm 89 \mathrm{~L} \mathrm{~kg}^{-1}$ of soil vs. $890 \pm 7 \mathrm{~L} \mathrm{~kg}^{-1}$ of soil; $P<0.05$ ) compared to the effects of redox conditions and topographic positions. For the remainder of the text, we will refer to PSI values as those calculated under $\mathrm{P}$ addition of $1000 \mathrm{mg} \mathrm{P} \mathrm{kg}^{-1}$ unless noted otherwise.

Rapid P sorption was observed in all soils, as at least $60 \%$ of the added $\mathrm{P}$ had disappeared from solution within the first $6 \mathrm{~h}$ of sorption experiment (Fig. 3). In the two slope soils, P sorption occurred more rapidly after anoxic incubation than after oxic incubation, as indicated by the lower concentrations of $\mathrm{P}$ remaining in solution under anoxic conditions (all $P<0.05$ after $12 \mathrm{~h}$ ). In valley soils from $\mathrm{El}$ Verde, however, $\mathrm{P}$ sorption occurred more rapidly after oxic incubation, as $2.6 \pm 0.4 \%$ vs. $30.3 \pm 3.3 \%$ of the added P remained in solution after the first $6 \mathrm{~h}$ after oxic and anoxic incubation, respectively $(P<0.001)$. In valley soils from Rio Icacos, more $\mathrm{P}$ was sorbed in soils from the oxic treatment than those from the anoxic treatment during the first $6 \mathrm{~h}($ all $P<0.05)$, while afterwards no effects of redox treatment were found. The rate of $\mathrm{P}$ sorption $(k)$ was strongly correlated with PSI values $(r=0.86, P<0.01$; Table 2$)$.

\subsection{Relationships of $\mathbf{P}$ sorption to other soil characteristics}

We explored the relationships between soil $\mathrm{Fe}$ and $\mathrm{Al}$ concentrations and $\mathrm{P}$ sorption indices. Among all samples, soil 
Table 2. Maximum $\mathrm{P}$ sorption capacities $\left(S_{\max }\right)$, rates of $\mathrm{P}$ sorption $(k)$, and soil $\mathrm{Fe}$ and $\mathrm{Al}$ fractions in response to redox treatments and their correlations with phosphorus sorption index (PSI) calculated from sorption data under $1000 \mathrm{mg} \mathrm{Pkg}^{-1}(n=4$ per treatment).

\begin{tabular}{|c|c|c|c|c|c|c|c|c|}
\hline Site & Position & Treatment & $\begin{array}{r}S_{\max } \\
\left(\mathrm{mg} \mathrm{Pkg}^{-1}\right)\end{array}$ & $k$ & $\begin{array}{l}\mathrm{HCl}-\mathrm{Fe}(\mathrm{II}) \\
\left(\mathrm{g} \mathrm{Fe} \mathrm{kg}^{-1}\right)\end{array}$ & $\begin{array}{l}\mathrm{HCl}-\mathrm{Fe}(\mathrm{III}) \\
\left(\mathrm{g} \mathrm{Fe} \mathrm{kg}^{-1}\right)\end{array}$ & $\begin{array}{r}\mathrm{AO}-\mathrm{Fe} \\
\left(\mathrm{g} \mathrm{Fe} \mathrm{kg}^{-1}\right)\end{array}$ & $\begin{array}{r}\mathrm{AO}-\mathrm{Al} \\
\left(\mathrm{g} \mathrm{Al} \mathrm{kg}^{-1}\right)\end{array}$ \\
\hline \multirow{2}{*}{ El Verde } & Slope & $\begin{array}{l}\text { Anoxic } \\
\text { Oxic }\end{array}$ & $\begin{array}{l}4893 \pm 562 \\
4352 \pm 387 \\
\end{array}$ & $\begin{array}{l}0.275 \pm 0.020 \\
0.244 \pm 0.016\end{array}$ & $\begin{array}{r}3.37 \pm 0.12 \mathrm{a} \\
0.038 \pm 0.003 \mathrm{~b} \\
\end{array}$ & $\begin{array}{l}0.86 \pm 0.09 \mathrm{~b} \\
1.55 \pm 0.12 \mathrm{a}\end{array}$ & $\begin{array}{l}0.92 \pm 0.06 a \\
0.75 \pm 0.09 a\end{array}$ & $\begin{array}{l}0.29 \pm 0.03 a \\
0.30 \pm 0.03 a\end{array}$ \\
\hline & Valley & $\begin{array}{l}\text { Anoxic } \\
\text { Oxic }\end{array}$ & $\begin{array}{r}6569 \pm 487 \\
7282 \pm 1207\end{array}$ & $\begin{array}{l}0.288 \pm 0.027 \\
0.486 \pm 0.049\end{array}$ & $\begin{array}{r}13.72 \pm 0.22 a \\
4.06 \pm 0.69 b\end{array}$ & $\begin{array}{l}1.85 \pm 0.08 b \\
5.63 \pm 0.55 a\end{array}$ & $\begin{array}{l}1.37 \pm 0.03 a \\
1.33 \pm 0.23 a\end{array}$ & $\begin{array}{r}0.20 \pm 0.004 a \\
0.17 \pm 0.01 b\end{array}$ \\
\hline \multirow{2}{*}{ Rio Icacos } & Slope & $\begin{array}{l}\text { Anoxic } \\
\text { Oxic }\end{array}$ & $\begin{array}{r}5369 \pm 1056 \\
2627 \pm 303\end{array}$ & $\begin{array}{l}0.303 \pm 0.015 \\
0.194 \pm 0.013\end{array}$ & $\begin{array}{r}3.36 \pm 0.17 \mathrm{a} \\
0.060 \pm 0.002 b\end{array}$ & $\begin{array}{l}0.67 \pm 0.13 a \\
0.80 \pm 0.05 a\end{array}$ & $\begin{array}{l}0.29 \pm 0.01 \mathrm{a} \\
0.31 \pm 0.03 \mathrm{a}\end{array}$ & $\begin{array}{l}1.00 \pm 0.04 \mathrm{a} \\
0.98 \pm 0.07 \mathrm{a}\end{array}$ \\
\hline & Valley & $\begin{array}{l}\text { Anoxic } \\
\text { Oxic }\end{array}$ & $\begin{array}{r}8256 \pm 2519 \\
3290 \pm 250\end{array}$ & $\begin{array}{l}0.365 \pm 0.022 \\
0.353 \pm 0.025\end{array}$ & $\begin{array}{r}3.39 \pm 0.30 \mathrm{a} \\
0.193 \pm 0.124 \mathrm{~b}\end{array}$ & $\begin{array}{l}0.90 \pm 0.06 a \\
0.92 \pm 0.10 a\end{array}$ & $\begin{array}{r}0.29 \pm 0.004 b \\
0.34 \pm 0.01 \mathrm{a}\end{array}$ & $\begin{array}{l}2.01 \pm 0.05 a \\
1.89 \pm 0.05 a\end{array}$ \\
\hline \multicolumn{2}{|c|}{$\begin{array}{l}\text { Correlation with } \\
\text { PSI }(n=32)\end{array}$} & $\begin{array}{l}r \\
P\end{array}$ & $\begin{array}{l}0.673^{\mathrm{a}} \\
0.068^{\mathrm{a}}\end{array}$ & $\begin{array}{l}0.863^{\mathrm{a}} \\
0.006^{\mathrm{a}}\end{array}$ & $\begin{array}{l}0.092 \\
0.616\end{array}$ & $\begin{array}{l}0.434 \\
0.013\end{array}$ & $\begin{array}{l}0.001 \\
0.998\end{array}$ & $\begin{array}{l}0.395 \\
0.028\end{array}$ \\
\hline
\end{tabular}

Means and SE are shown. Different letters indicate significant effects of redox treatment in each combination of site and topographic position ( $t$ tests). Significant correlation coefficient $(r)$ and $P$ values are in bold. ${ }^{\mathrm{a}} n=8$.

$\mathrm{HCl}-\mathrm{Fe}(\mathrm{III})$ concentrations were weakly positively correlated with PSI values $(r=0.43, P<0.05$; Table 2$)$, while $\mathrm{HCl}$ $\mathrm{Fe}$ (II) values were not. The correlation between $\mathrm{HCl}-\mathrm{Fe}(\mathrm{III})$ and PSI was strongest at El Verde (Fig. S2; $r=0.89, P<$ 0.001). Among all samples, concentrations of AO-Al were weakly positively correlated with PSI values $(r=0.39, P<$ $0.05)$, but AO-Fe concentrations were not. A positive correlation between AO-Al concentrations and PSI was found at Rio Icacos (Fig. S2; $r=0.74, P=0.002$ ), while their correlation was negative at El Verde $(r=-0.71, P=0.002)$.

\subsection{Phosphorus solubility}

We explored the solubility of $\mathrm{P}$ following $\mathrm{P}$ additions at the El Verde site. Phosphorus additions of $100 \mathrm{mg} \mathrm{Pkg}^{-1}$ yielded higher relative $\mathrm{P}$ solubility than $1000 \mathrm{mg} \mathrm{Pg}^{-1}$ additions, in both $\mathrm{NaHCO}_{3}(P<0.001$; Fig. 4$)$ and $\mathrm{NaOH}$ solutions $(P<0.001)$, as extractants might have reached their limits of dissolving $\mathrm{P}$ under a higher $\mathrm{P}$ addition level. Anoxic conditions generally increased $\mathrm{P}$ solubility in $\mathrm{NaHCO}_{3}$ solution except in the slope soil with $\mathrm{P}$ addition of $100 \mathrm{mg} \mathrm{Pkg}^{-1}$. Phosphorus solubility in $\mathrm{NaOH}$ solution decreased in the anoxic treatment in the valley soil with the lower level of $\mathrm{P}$ addition only $(P<0.001)$. Note that anoxic conditions increased PSI values in both soils under $\mathrm{P}$ additions of $1000 \mathrm{mg} \mathrm{P} \mathrm{kg}^{-1}$ (Fig. S3). The average relative solubility of $\mathrm{P}$ was much lower in $\mathrm{NaHCO}_{3}$ solution than in $\mathrm{NaOH}$ solution $(20.5 \pm 1.3 \%$ vs. $69.7 \pm 2.1 \% ; P<0.001)$.

\section{Discussion}

\subsection{Anoxic conditions maintained high P sorption}

Contrary to our first hypothesis that anoxic conditions would decrease $\mathrm{P}$ sorption, anoxic conditions led to similar or greater rates $(k)$ of $\mathrm{P}$ sorption as oxic conditions in all but one treatment (P sorption time curve for El Verde valley). This suggests that soils remain strong $P$ sinks even under reducing conditions. Under both oxic and anoxic conditions, estimated maximum $\mathrm{P}$ sorption capacities were much higher than the range of total soil P concentrations (Mage and Porder, 2012), highlighting the significant potential of these soils for retaining P. Our estimates of $S_{\max }$ were relatively high relative to other humid tropical soils. For example, de Campos et al. (2016) applied up to $8000 \mathrm{mg} \mathrm{Pgg}^{-1}$ to a set of strongly weathered Brazilian forest soils and reported a wide range of $S_{\max }$ values (61-5460 $\mathrm{mg} \mathrm{Pkg}^{-1}$ ). Compared to our preliminary trials with maximum $\mathrm{P}$ addition of $1000 \mathrm{mg} \mathrm{Pkg}^{-1}$ (Fig. S1), $S_{\max }$ values were higher when more $\mathrm{P}$ was added (5000 and $10000 \mathrm{mg} \mathrm{Pkg}^{-1}$; Table 2), suggesting that $S_{\max }$ can be influenced by the concentrations of $\mathrm{P}$ used in the experiment. However, even when the maximum $\mathrm{P}$ addition level was similar (up to $1500 \mathrm{mg} \mathrm{Pkg}^{-1}$ of soil), $S_{\max }$ values from the preliminary trials were also high compared to other strongly weathered soils, including Brazilian forest soils (295-1167 $\mathrm{mg} \mathrm{Pkg}^{-1}$; Roy et al., 2017) and Thai upland soils (47-1250 $\mathrm{m} \mathrm{P} \mathrm{kg}^{-1}$; Wisawapipat et al., 2009). Sorption of $\mathrm{P}$ occurred very rapidly under both redox conditions, with over $60 \%$ of the added $\mathrm{P}$ removed from solution within $6 \mathrm{~h}$ in all soils. Results indicate that low-redox events are unlikely to induce significant $\mathrm{P}$ release to the soil solution in these soils. High $\mathrm{P}$ sorption potential is very likely responsible for the extremely low $\mathrm{P}$ concentrations of stream water in local watersheds (McDowell, 1998; McDowell and Liptzin, 2014). Our results also suggest that new P entering the ecosystem via atmospheric sources such as dust or smoke (Pett-Ridge, 2009) would likely be rapidly sorbed by soil minerals.

Three mechanisms are likely responsible for the high $\mathrm{P}$ sorption capacities under anoxic conditions. First, mixed 


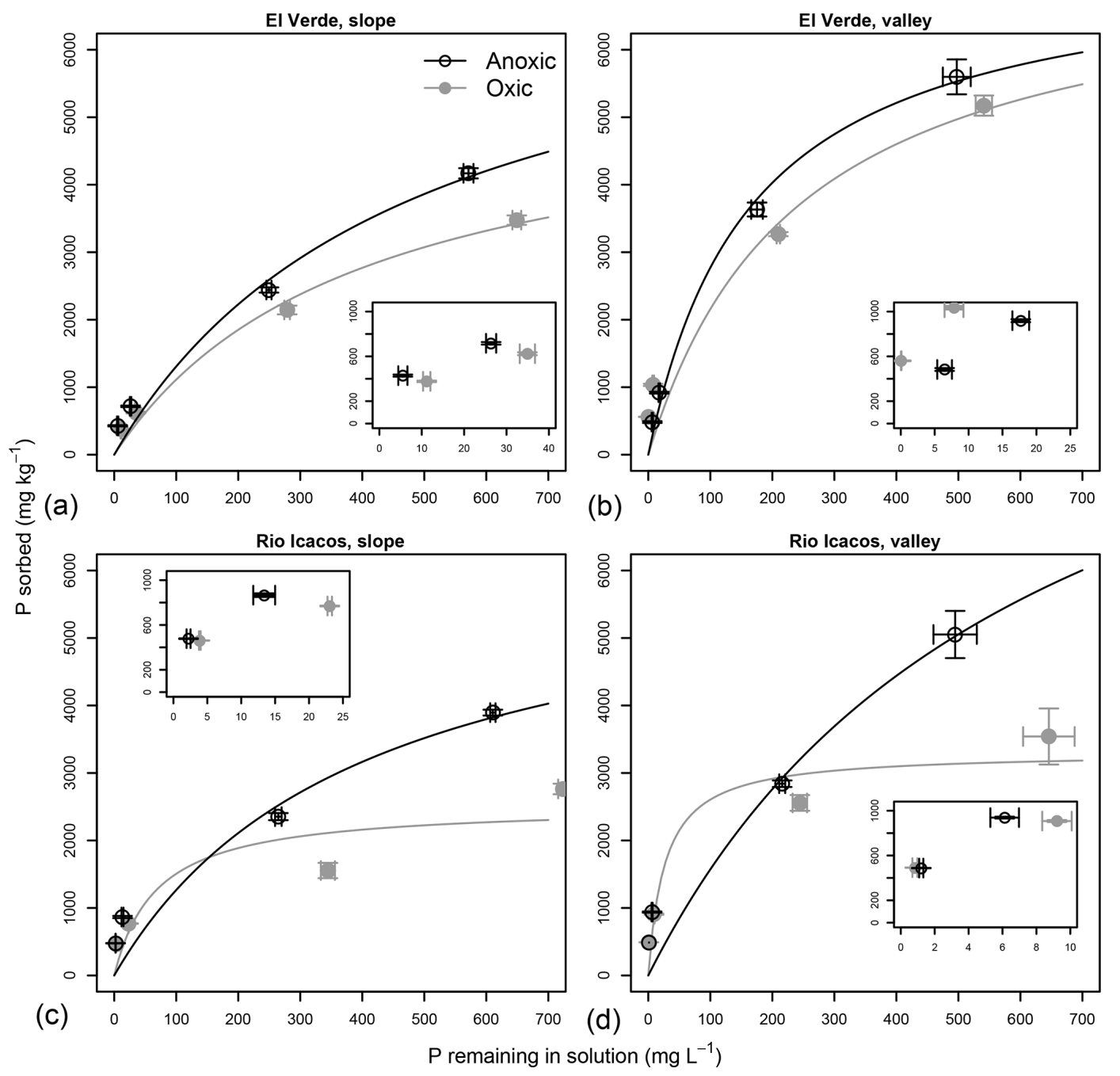

Figure 1. Effects of anoxic vs. oxic pre-incubation on the P sorption isotherms of slope (a, c) and valley (b, d) soils from El Verde (a, b) and Rio Icacos (c, d). Means and standard errors of means are shown. Insets are the zoomed-in versions of the lower left portion of the respective plots.

$\mathrm{Fe}(\mathrm{III})-\mathrm{Fe}(\mathrm{II})$ or $\mathrm{Fe}(\mathrm{II})$ minerals formed during Fe reduction may have a high sorption capacity. Past research in this ecosystem has shown that approximately $90 \%$ of the $\mathrm{HCl}-$ extractable $\mathrm{Fe}(\mathrm{II})$ was in the mineral phase (Peretyazhko and Sposito, 2005; Wilmoth et al., 2018; Chen et al., 2018). These minerals can feature a more amorphous structure compared to $\mathrm{Fe}(\mathrm{III})$ phases and thus have a higher surface area available for P sorption (Patrick and Khalid, 1974; Holford and Patrick, 1979; Borch and Fendorf, 2007). Soils from the study site have very large and diverse populations of microbial Fe reducers that facilitate rapid Fe reduction (Dubinsky et al., 2010), contributing to the formation and maintenance of high amorphous Fe minerals. Second, Fe reduction is known to increase soil pH (Lindsay, 1979) that consequently increases the degree of hydroxylation and surface area of $\mathrm{Al}$ and organo-Al complexes (Haynes, 1982). These changes in $\mathrm{Al}$ speciation have commonly been used to explain the increased P sorption capacities under liming (Haynes and Swift, 1989; Gustafsson et al., 2012). Finally, formation of $\mathrm{Fe}(\mathrm{II})-\mathrm{P}$ minerals, such as vivianite, can also contribute to high P retention (Heiberg et al., 2012; Walpersdorf et al., 2013). In our experiment, the soil slurry appeared to be supersaturated with respect to vivianite precipitation, especially under high $\mathrm{P}$ loadings (5000 and $10000 \mathrm{mg} \mathrm{P} \mathrm{kg}^{-1}$; Table S3). However, the effect of vivianite formation was likely to be small under lower $\mathrm{P}$ loadings (e.g., $1000 \mathrm{mg} \mathrm{P} \mathrm{kg}^{-1}$ ), as its precipitation kinetics are slow and depend on $\mathrm{P}$ concentration (Borch and Fendorf, 2007; Heiberg et al., 2012).

\subsection{Phosphorus sorption and Fe and Al minerals}

Our results identified amorphous $\mathrm{Fe}(\mathrm{III})$ and $\mathrm{Al}$ minerals as the best predictors of soil PSI values but not Fe(II) minerals. These results suggest that soil $\mathrm{Fe}(\mathrm{II})$ minerals alone were in- 
El Verde

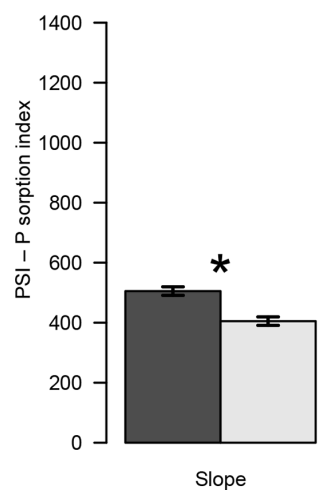

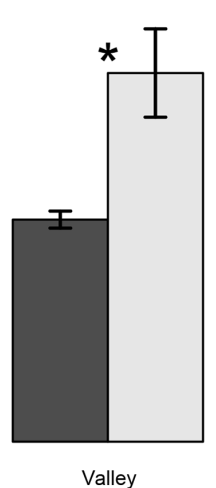
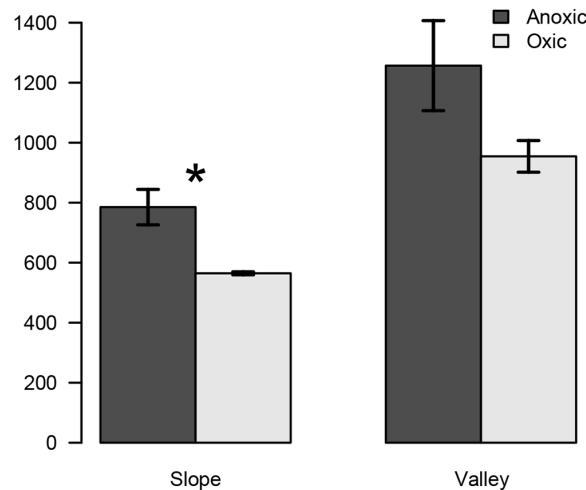

Figure 2. Effects of anoxic vs. oxic pre-incubation on the P sorption index (PSI) of slope and valley soils from El Verde and Rio Icacos. The PSI values were calculated from sorption isotherm data under $1000 \mathrm{mg} \mathrm{Pkg}^{-1}$, which better represented $\mathrm{P}$ sorption behavior under low levels of $\mathrm{P}$ addition than the estimated maximum $\mathrm{P}$ sorption capacity. Means and standard errors of means are shown. * indicates significant difference of PSI for the respective combination of site and topographic position.

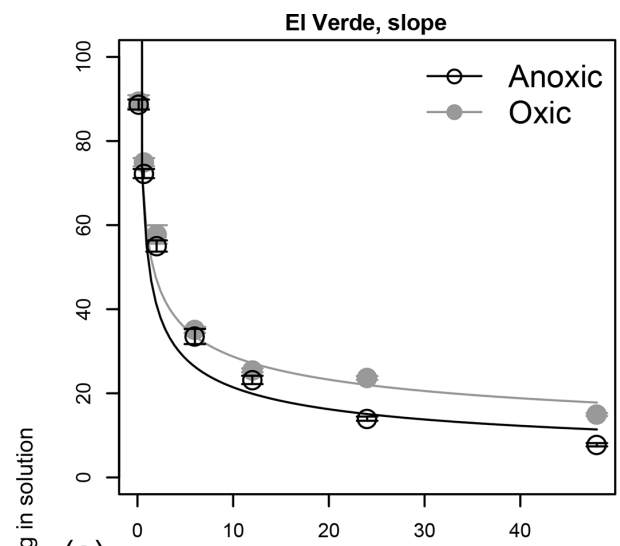

(a)

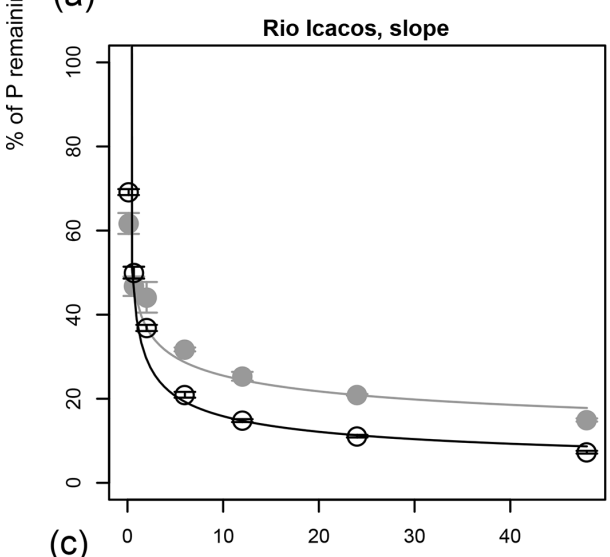

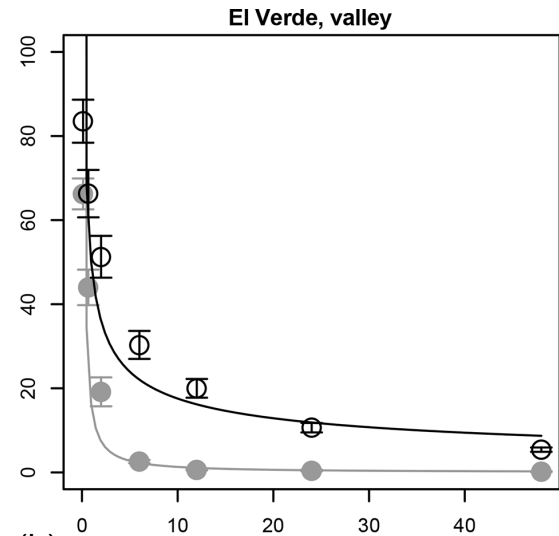

(b)

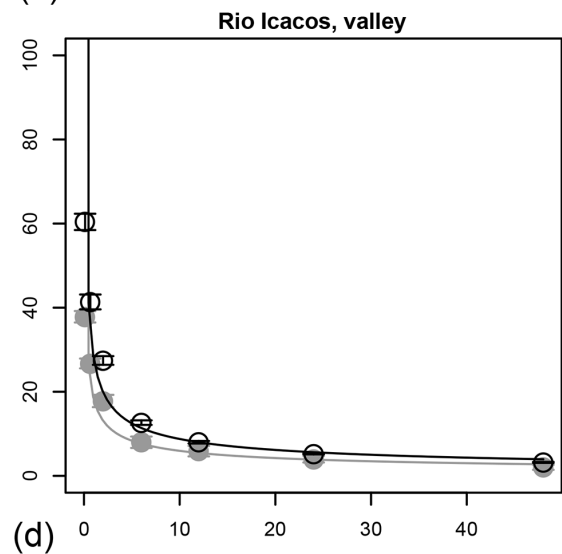

Time (h)

Figure 3. Effects of anoxic vs. oxic pre-incubation on the $\mathrm{P}$ sorption time curves of slope (a, c) and valley (b, d) soils from El Verde (a, b) and Rio Icacos (c, d). Phosphorus was added at the level of $1000 \mathrm{mg} \mathrm{Pkg}^{-1}$. Means and standard errors of means are shown. 


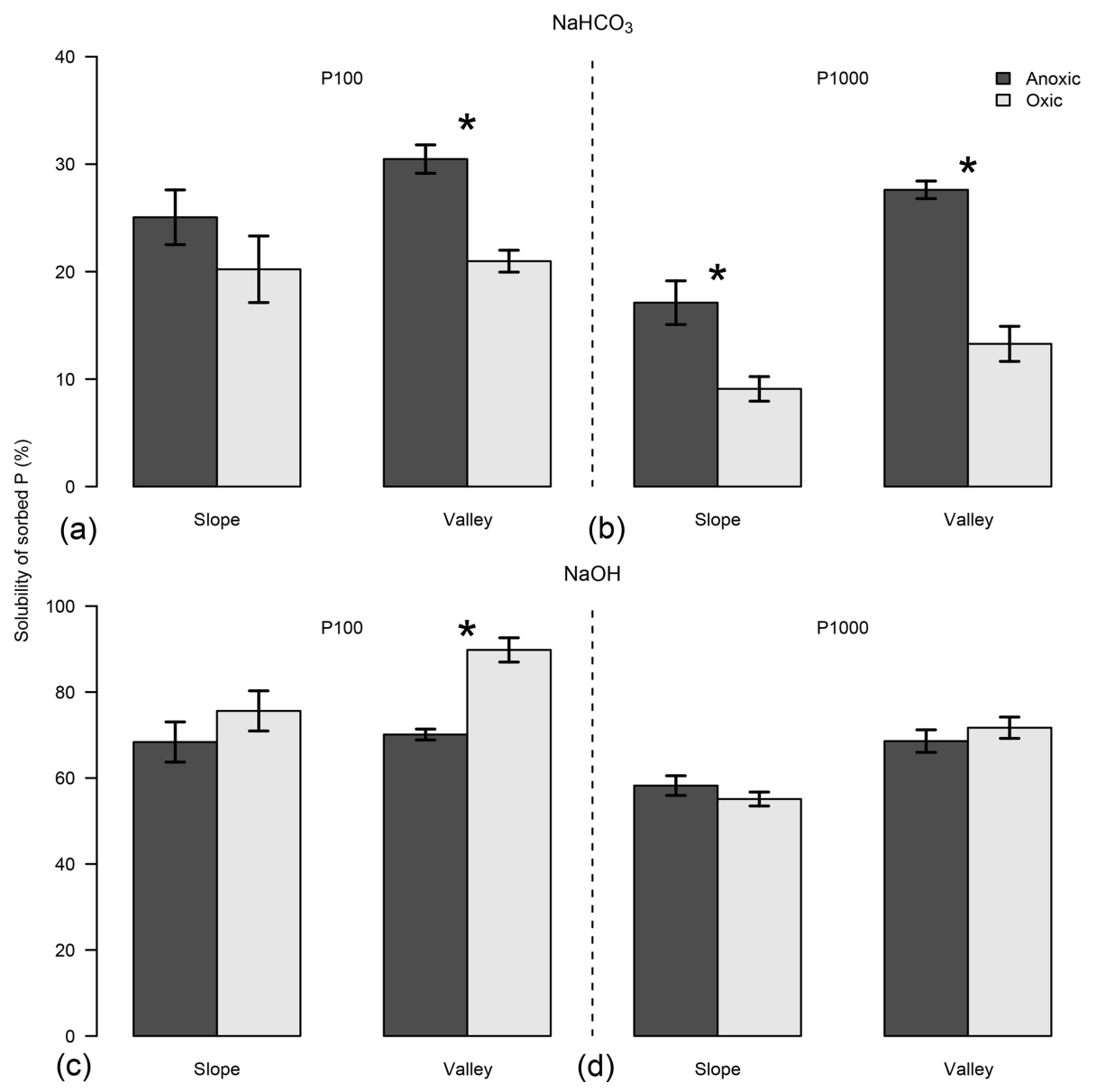

Figure 4. Effects of anoxic vs. oxic pre-incubation on the relative solubility of the sorbed $\mathrm{P}$ in $\mathrm{NaHCO}_{3}$ and $\mathrm{NaOH}$ solution under $\mathrm{P}$ addition of $100 \mathrm{mg} \mathrm{Pkg}^{-1}$ (P100; a, c) and $1000 \mathrm{mg} \mathrm{Pkg}^{-1}$ (P1000; b, d). Soils were collected from slope and valley positions at El Verde. Means and standard errors of means are shown. * indicates significant difference of PSI for the respective combination of site, topographic position, and level of $\mathrm{P}$ addition.

sufficient to explain P sorption capacity compared to Fe(III) or Al minerals, consistent with previous studies (Sallade and Sims, 1997; Quintero et al., 2007; Rakotoson et al., 2014). However, soil $\mathrm{Fe}(\mathrm{III})$ and $\mathrm{Al}$ minerals were less responsive to redox manipulation compared to $\mathrm{Fe}(\mathrm{II})$ minerals. Persistence of amorphous minerals, as well as crystalline $\mathrm{Fe}$ and $\mathrm{Al}$ minerals, are all likely contributors to the high $\mathrm{P}$ sorption capacity under both redox conditions (Gérard, 2016; McGechan and Lewis, 2002). We found that anoxic conditions did not affect $\mathrm{HCl}-\mathrm{Fe}(\mathrm{III})$ concentrations in soils from Rio Icacos and that changes in $\mathrm{HCl}-\mathrm{Fe}(\mathrm{III})$ and $\mathrm{AO}-\mathrm{Fe}$ were smaller in magnitude compared to the increases in $\mathrm{HCl}-\mathrm{Fe}(\mathrm{II})$ across all soil types. Together, this indicates that Fe reduction mobilized crystalline or poorly crystalline Fe that was not soluble in $\mathrm{HCl}$ or $\mathrm{AO}$ solution. Appan and Wang (2000) found no effects of redox on P sorption in tropical reservoir sediments with high $\mathrm{Al}$ concentrations. Overall, concentrations of soil $\mathrm{Fe}$ (III) and $\mathrm{Al}$ minerals influenced soil $\mathrm{P}$ sorption behavior across soil types, and their persistence contributed to high $\mathrm{P}$ sorption under both redox environments.
Patterns in soil $\mathrm{Fe}$ and $\mathrm{Al}$ concentrations helped to explain the variability in soil $\mathrm{P}$ sorption behavior across the two topographic zones. Valley soils, which are characterized by frequent high-magnitude redox fluctuations and low-redox events (Silver et al., 1999), had higher concentrations of HCl$\mathrm{Fe}(\mathrm{III})$ than slope soils at both sites and had similar or higher levels of AO-Fe. The valley soil at Rio Icacos had twice as much AO-Al as the slope soil. The higher levels of amorphous $\mathrm{Fe}$ and $\mathrm{Al}$ minerals in valley soils likely contributed to higher PSI values relative to slopes in both locations. The differences in amorphous $\mathrm{Fe}$ and $\mathrm{Al}$ concentrations likely resulted from the long-term changes in redox history and soil transport along the catena (Hall and Silver, 2015; Mage and Porder, 2012). Water and organic-matter transport leads to higher soil moisture content in valleys than in slope soils and helps to create more frequent and intensive reducing events (Silver et al., 1999). These conditions facilitate the formation and persistence of amorphous $\mathrm{Fe}$ and $\mathrm{Al}$ minerals.

Differences in $\mathrm{Fe}$ and $\mathrm{Al}$ minerals also helped to explain the patterns of P sorption across two sites. Soils at El Verde 
were enriched in $\mathrm{HCl}-\mathrm{Fe}(\mathrm{III})$ and $\mathrm{AO}-\mathrm{Fe}$ but depleted in $\mathrm{AO}$ Al compared to soils at Rio Icacos, and the positive correlation between $\mathrm{HCl}-\mathrm{Fe}(\mathrm{III})$ and PSI was only significant at El Verde. Soil AO-Al concentrations were positively correlated with PSI at Rio Icacos but had a negative correlation at El Verde. These results suggest that Fe minerals may play a primary role in sorbing $\mathrm{P}$ in the volcanoclastic soils, while $\mathrm{Al}$ minerals were more important to $\mathrm{P}$ sorption in the dioritic soils. Together our results show that redox history and parent material influenced the patterns of soil P sorption across topographic zones and study site, respectively, at long timescales.

In the valley soil from El Verde, the effects of redox manipulation on $\mathrm{P}$ sorption differed greatly among levels of $\mathrm{P}$ addition, a pattern not observed in the other three sampling sites. High concentrations of $\mathrm{Fe}(\mathrm{II})$, derived from the low-redox legacy of the soil, and soluble $\mathrm{P}$ under high $\mathrm{P}$ loadings (5000 and $10000 \mathrm{mg} \mathrm{kg}^{-1}$ ) represented favorable conditions for vivianite formation (Table S3), which likely contributed to the higher $\mathrm{P}$ sorption capacity under anoxic conditions in this soil. Vivianite formation did not appear to play a major role in $\mathrm{P}$ sorption at a lower $\mathrm{P}$ loading $\left(1000 \mathrm{mg} \mathrm{P} \mathrm{kg}^{-1}\right)$, as the anoxic treatment decreased the PSI value and $\mathrm{P}$ sorption rate $(k)$ in this soil. The strong decline in amorphous $\mathrm{Fe}$ (III) concentrations as a result of Fe reduction was potentially responsible for the reduced PSI and P sorption rate under anoxic conditions in these soils. The specific effects of different $\mathrm{P}$ loadings under redox manipulation also led to the lack of significant correlation between $S_{\max }$ and PSI values because $S_{\max }$ was mostly driven by data from high P loadings, while PSI was calculated at the P loading of $1000 \mathrm{mg} \mathrm{Pkg}^{-1}$.

The PSI values of the valley soil at El Verde showed different responses to anoxic incubation in two separate trials. Soil moisture content measured in the P solubility experiment was significantly lower than its mean value calculated from continuous field observations (O'Connell et al., 2018) and lower than that measured in the initial trial, likely due to natural background variability in rainfall. The PSI value and its response to redox manipulation resembled those of the slope soil. It is possible that the dry period decreased the reactive surface areas of soil minerals potentially by oxidizing reduced species and increasing the crystallinity of secondary $\mathrm{Fe}$ and $\mathrm{Al}$ minerals. These results suggest that soil $\mathrm{P}$ dynamics could be highly sensitive to changes in environmental conditions in tropical forests (O'Connell et al., 2018).

\subsection{Implications for $P$ solubility and bioavailability}

Our results showed that, regardless of redox conditions, significantly more $\mathrm{P}$ was soluble in $\mathrm{NaOH}$ than $\mathrm{NaHCO}_{3}$ and that the relative $\mathrm{P}$ solubility was high ( $>50 \%$ of sorbed $\mathrm{P}$ ) in $\mathrm{NaOH}$ for both the 100 and $1000 \mathrm{mg} \mathrm{Pg}^{-1}$ additions. The $\mathrm{NaOH}$ extraction is stronger than the $\mathrm{NaHCO}_{3}$ solution, and together they are thought to represent a continuum of
$\mathrm{P}$ bound to $\mathrm{Fe}$ and $\mathrm{Al}$ minerals (Tiessen and Moir, 1993). Anoxic conditions generally increased the solubility of the sorbed $\mathrm{P}$ in $\mathrm{NaHCO}_{3}$ solution, indicating that the strength of $\mathrm{P}$ sorption was weaker when soils had more anaerobic microsites. The change in $\mathrm{P}$ sorption likely reflected the lower binding strengths of reduced Fe minerals to $\mathrm{P}$ than their oxidized forms (Zhang et al., 2003; Holford and Patrick, 1979). Past research has reported increased extractable $\mathrm{P}$ in response to Fe reduction using soils from the tropics (Peretyazhko and Sposito, 2005; Liptzin and Silver, 2009; Chacón et al., 2006; Maranguit et al., 2017; Lin et al., 2018). Our results suggest that Fe-redox dynamics decrease the strength, rather than the capacity, of soil P sorption.

Our results have important implications for understanding $\mathrm{P}$ bioavailability in tropical forest soils. These results suggest that reducing events can potentially increase $\mathrm{P}$ bioavailability by decreasing the $\mathrm{P}$ sorption strength of minerals even though $\mathrm{P}$ sorption capacity remained high. An interesting question for future studies is whether plant roots and microbes can take advantage of the increased $\mathrm{P}$ solubility during reducing events. Anaerobic conditions can be stressful for plants and microbes; however, studies have reported similar soil respiration rates under aerobic and anaerobic conditions in humid tropical forest soils (DeAngelis et al., 2010; Pett-Ridge, 2005; Bhattacharyya et al., 2018). Soil microbes appear to be well-adapted to dynamic redox conditions, at least at the scales of days to weeks. Thus, it is possible that microbes can benefit from the increased P solubility under anoxic conditions. At a watershed scale, topography and parent material are important controls of soil sorption behavior and $\mathrm{P}$ bioavailability. Although $\mathrm{P}$ sorption capacity was high in soils with high $\mathrm{Fe}$ and $\mathrm{Al}$ concentrations, these soils also responded more strongly to reducing events. Thus, redox dynamics may be particularly important in these soils to facilitate biological uptake and ecosystem retention of $\mathrm{P}$.

\section{Conclusions}

We found that minerals can retain high $\mathrm{P}$ sorption capacity during reducing events in highly weathered tropical forest soils. Their high P sorption capacity is expected to contribute to low $\mathrm{P}$ concentrations in soil solution and limit the potential for P leaching. Due to the high P sorption capacity in tropical soils, current and future increases in precipitation associated with climate change are unlikely to drastically alter $\mathrm{P}$ leaching in these environments. Reducing events also decreased the strength of $\mathrm{P}$ sorption and potentially increased $\mathrm{P}$ bioavailability. Thus, episodic reducing events could serve as "hot moments" for plants and microbes to acquire soil $\mathrm{P}$ that would otherwise be tightly bound to minerals. As a result of altered rainfall regimes, more frequent or intensive redox oscillation could increase $\mathrm{P}$ bioavailability if it does not impose a strong $\mathrm{O}_{2}$ limitation on primary productivity or decomposition. 
Data availability. Data used to produce tables and figures are available at http://www.hydroshare.org/resource/ 36b97e432cd44f42867fd019dbe4cf19 (last access: 18 November 2019; Lin et al., 2019).

Supplement. The supplement related to this article is available online at: https://doi.org/10.5194/bg-17-89-2020-supplement.

Author contributions. YL, AG, and WLS conceived the study. YL, AG, and CSO'C performed the research. YL led the paper development and data analysis, and all authors contributed to writing.

Competing interests. The authors declare that they have no conflict of interest.

Acknowledgements. We thank Summer Ahmed, Heather Dang, Jordan Stark, Omar Gutiérrez del Arroyo, Sarah Stankavich, and Gisela Gonzalez for their support in the laboratory and in the field. This study benefited from discussions with Aaron Thompson, Chunmei Chen, Steven Hall, and Tyler Anthony.

Financial support. This research has been supported by the National Science Foundation (grant nos. DEB-1457805, EAR1331841, and DEB-0620910), the US Department of Energy (grant no. TES-DE-FOA-0000749), and the National Institute of Food and Agriculture (grant no. CA-B-ECO-7673-MS).

Review statement. This paper was edited by Anja Rammig and reviewed by Eric Roy and Luis Carlos Colocho Hurtarte.

\section{References}

Appan, A. and Wang, H.: Sorption isotherms and kinetics of sediment phosphorus in a tropical reservoir, J. Environ. Eng., 126, 993-998, 2000.

Bache, B. W. and Williams, E. G.: A phosphate sorption index for soils, J. Soil Sci., 22, 289-301, 1971.

Barcellos, D., Cyle, K. T., and Thompson, A.: Faster redox fluctuations can lead to higher iron reduction rates in humid forest soils, Biogeochemistry, 137, 367-378, https://doi.org/10.1007/s10533018-0427-0, 2018.

Bhattacharyya, A., Campbell, A. N., Tfaily, M. M., Lin, Y., Kukkadapu, R. K., Silver, W., Nico, P. S., and Pett-Ridge, J.: Redox fluctuations control the coupled cycling of iron and carbon in tropical forest soils, Environ. Sci. Technol., 52, 14129-14139, https://doi.org/10.1021/acs.est.8b03408, 2018.

Bolster, C. H. and Hornberger, G. M.: On the use of linearized Langmuir equations, Soil Sci. Soc. Am. J., 71, 1796, https://doi.org/10.2136/sssaj2006.0304, 2007.

Borch, T. and Fendorf, S.: Chapter 12 Phosphate Interactions with Iron (Hydr)oxides: Mineralization Pathways and Phosphorus Re- tention upon Bioreduction, Developments in Earth and Environmental Sciences, 7, 321-348, https://doi.org/10.1016/S15719197(07)07012-7, 2007.

Borggaard, O. K., Jørgensen, S. S., Møberg, J. P., and Raben-Lange, B.: Influence of organic matter on phosphate adsorption by aluminium and iron oxides in sandy soils, J. Soil Sci., 41, 443-449, https://doi.org/10.1111/j.1365-2389.1990.tb00078.x, 1990.

Brown, S., Lugo, A. E., Silander, S., and Liegel, L.: Research history and opportunities in the Luquillo Experimental Forest, U.S. Department of Agriculture Forest Service, General Technical Report SO-44, Southern Forest Experiment Station, New Orleans, LA, 128 pp., 1983.

Camenzind, T., Hättenschwiler, S., Treseder, K. K., Lehmann, A., and Rillig, M. C.: Nutrient limitation of soil microbial processes in tropical forests, Ecol. Monogr., 88, 4-21, https://doi.org/10.1002/ecm.1279, 2017.

Chacón, N., Silver, W. L., Dubinsky, E. A., and Cusack, D. F.: Iron reduction and soil phosphorus solubilization in humid tropical forests soils: The roles of labile carbon pools and an electron shuttle compound, Biogeochemistry, 78, 67-84, https://doi.org/10.1007/s10533-005-2343-3, 2006.

Chen, C., Meile, C., Wilmoth, J. L., Barcellos, D., and Thompson, A.: Influence of $\mathrm{pO}_{2}$ on iron redox cycling and anaerobic organic carbon mineralization in a humid tropical forest soil, Environ. Sci. Technol., 52, 7709-7719, 2018.

Cleveland, C. C., Townsend, A. R., Taylor, P., Alvarez-Clare, S., Bustamante, M., Chuyong, G., Dobrowski, S. Z., Grierson, P., Harms, K. E., and Houlton, B. Z.: Relationships among net primary productivity, nutrients and climate in tropical rain forest: a pan-tropical analysis, Ecol. Lett., 14, 939-947, 2011.

Coward, E. K., Thompson, A. T., and Plante, A. F.: Ironmediated mineralogical control of organic matter accumulation in tropical soils, Geoderma, 306, 206-216, https://doi.org/10.1016/j.geoderma.2017.07.026, 2017.

DeAngelis, K. M., Silver, W. L., Thompson, A. W., and Firestone, M. K.: Microbial communities acclimate to recurring changes in soil redox potential status, Environ. Microbiol., 12, 3137-3149, https://doi.org/10.1111/j.1462-2920.2010.02286.x, 2010.

de Campos, M., Antonangelo, J. A., and Alleoni, L. R. F.: Phosphorus sorption index in humid tropical soils, Soil Till. Res., 156, 110-118, https://doi.org/10.1016/j.still.2015.09.020, 2016.

Dubinsky, E. A., Silver, W. L., and Firestone, M. K.: Tropical forest soil microbial communities couple iron and carbon biogeochemistry, Ecology, 91, 2604-2612, https://doi.org/10.1890/091365.1, 2010.

Gérard, F.: Clay minerals, iron/aluminum oxides, and their contribution to phosphate sorption in soils - A myth revisited, Geoderma, 262, 213-226, https://doi.org/10.1016/j.geoderma.2015.08.036, 2016.

Gross, A., Pett-Ridge, J., and Silver, W.: Soil Oxygen Limits Microbial Phosphorus Utilization in Humid Tropical Forest Soils, Soil Systems, 2, 65, https://doi.org/10.3390/soilsystems2040065, 2018.

Gustafsson, J. P.: Visual MINTEQ 3.1 user guide. KTH, Department of Land and Water Recources, Stockholm, Sweden, available at: https://vminteq.lwr.kth.se/ (last access: 22 July 2019), 2015.

Gustafsson, J. P., Mwamila, L. B., and Kergoat, K.: The $\mathrm{pH}$ dependence of phosphate sorption and desorption in 
Swedish agricultural soils, Geoderma, 189-190, 304-311, https://doi.org/10.1016/j.geoderma.2012.05.014, 2012.

Hall, S. J. and Silver, W. L.: Reducing conditions, reactive metals, and their interactions can explain spatial patterns of surface soil carbon in a humid tropical forest, Biogeochemistry, 125, 149165, https://doi.org/10.1007/s10533-015-0120-5, 2015.

Haynes, R. J.: Effects of liming on phosphate availability in acid soils, Plant Soil, 68, 289-308, https://doi.org/10.1007/BF02197935, 1982.

Haynes, R. J. and Swift, R. S.: The effects of $\mathrm{pH}$ and drying on adsorption of phosphate by aluminium-organic matter associations, J. Soil Sci., 40, 773-781, https://doi.org/10.1111/j.13652389.1989.tb01317.x, 1989.

Hedley, M. J., Stewart, J. W. B., and Chauhan, B.: Changes in inorganic and organic soil phosphorus fractions induced by cultivation practices and by laboratory incubations, Soil Sci. Soc. Am. J., 46, 970-976, 1982.

Heiberg, L., Koch, C. B., Kjaergaard, C., Jensen, H. S., and Hans Christian, B. H.: Vivianite precipitation and phosphate sorption following iron reduction in anoxic soils, J. Environ. Qual., 41, 938-949, https://doi.org/10.2134/jeq2011.0067, 2012.

Henry, P. C. and Smith, M. F.: Two-step approach to determining some useful phosphorus characteristics of South African soils: a review of work done at the ARC-Institute for Soil, Climate and Water, South African Journal of Plant and Soil, 23, 64-72, 2006.

Holford, I. C. R. and Patrick, W. H.: Effects of reduction and $\mathrm{pH}$ changes on phosphate sorption and mobility in an acid soil, Soil Sci. Soc. Am. J., 43, 292-297, 1979.

Johnson, A. H., Frizano, J., and Vann, D. R.: Biogeochemical implications of labile phosphorus in forest soils determined by the Hedley fractionation procedure, Oecologia, 135, 487-499, https://doi.org/10.1007/s00442-002-1164-5, 2003.

Keiluweit, M., Nico, P. S., Kleber, M., and Fendorf, S.: Are oxygen limitations under recognized regulators of organic carbon turnover in upland soils?, Biogeochemistry, 127, 157-171, https://doi.org/10.1007/s10533-015-0180-6, 2016.

Lin, Y., Bhattacharyya, A., Campbell, A. N., Nico, P. S., Pett-Ridge, J., and Silver, W. L.: Phosphorus fractionation responds to dynamic redox conditions in a humid tropical forest soil, J. Geophys. Res.-Biogeo., 123, 3016-3027, https://doi.org/10.1029/2018JG004420, 2018.

Lin, Y., Gross, A., O'Connell, C. S., and Silver, W. L.: Anoxic conditions maintained high phosphorus sorption in humid tropical forest soils, HydroShare, available at: http://www.hydroshare. org/resource/36b97e432cd44f42867fd019dbe4cf19, last access: 18 November 2019.

Lindsay, W. L.: Iron, in: Chemical equilibria in soils, edited by: Lindsay, W. L., John Wiley and Sons Ltd., Chichester, UK, 129149, 1979.

Liptzin, D. and Silver, W. L.: Effects of carbon additions on iron reduction and phosphorus availability in a humid tropical forest soil, Soil Biol. Biochem., 41, 1696-1702, https://doi.org/10.1016/j.soilbio.2009.05.013, 2009.

Mage, S. M. and Porder, S.: Parent material and topography determine soil phosphorus status in the Luquillo Mountains of Puerto Rico, Ecosystems, 16, 284-294, https://doi.org/10.1007/s10021012-9612-5, 2012.

Maranguit, D., Guillaume, T., and Kuzyakov, Y.: Effects of flooding on phosphorus and iron mobilization in highly weathered soils under different land-use types: Shortterm effects and mechanisms, Catena, 158, 161-170, https://doi.org/10.1016/j.catena.2017.06.023, 2017.

McDowell, W. H.: Internal nutrient fluxes in a Puerto Rican rain forest, J. Trop. Ecol., 14, 521-536, https://doi.org/10.1017/S0266467498000376, 1998.

McDowell, W. H. and Liptzin, D.: Linking soils and streams: Response of soil solution chemistry to simulated hurricane disturbance mirrors stream chemistry following a severe hurricane, Forest Ecol. Manage., 332, 56-63, https://doi.org/10.1016/j.foreco.2014.06.001, 2014.

McGechan, M. B. and Lewis, D. R.: Sorption of Phosphorus by Soil, Part 1: Principles, Equations and Models, Biosyst. Eng., 82, 124, https://doi.org/10.1006/bioe.2001.0013, 2002.

Murphy, J. and Riley, J. P.: A modified single solution method for the determination of phosphate in natural waters, Anal. Chim. Acta, 27, 31-36, 1962.

Murphy, S. F., Stallard, R. F., Scholl, M. A., González, G., and Torres-Sánchez, A. J.: Reassessing rainfall in the Luquillo Mountains, Puerto Rico: Local and global ecohydrological implications, PLoS ONE, 12, e0180987, https://doi.org/10.1371/journal.pone.0180987, 2017.

O'Connell, C. S., Ruan, L., and Silver, W. L.: Drought drives rapid shifts in tropical rainforest soil biogeochemistry and greenhouse gas emissions, Nat. Commun., 9, 1348, https://doi.org/10.1038/s41467-018-03352-3, 2018.

Oh, Y. M., Hesterberg, D. L., and Nelson, P. V.: Comparison of phosphate adsorption on clay minerals for soilless root media, Commun. Soil Sci. Plan., 30, 747-756, 1999.

Olander, L. P. and Vitousek, P. M.: Biological and geochemical sinks for phosphorus in soil from a wet tropical forest, Ecosystems, 7, 404-419, https://doi.org/10.1007/s10021-004-0264-y, 2004.

Patrick, W. H. and Khalid, R. A.: Phosphate release and sorption by soils and sediments: effect of aerobic and anaerobic conditions, Science, 186, 53-55, 1974.

Peretyazhko, T. and Sposito, G.: Iron(III) reduction and phosphorous solubilization in humid tropical forest soils, Geochim. Cosmochim. Ac., 69, 3643-3652, https://doi.org/10.1016/j.gca.2005.03.045, 2005.

Pett-Ridge, J.: Rapidly fluctuating redox regimes frame the ecology of microbial communities and their biogeochemical function in a humid tropical soil, PhD, University of California, Berkeley, 2005.

Pett-Ridge, J. C.: Contributions of dust to phosphorus cycling in tropical forests of the Luquillo Mountains, Puerto Rico, Biogeochemistry, 94, 63-80, https://doi.org/10.1007/s10533-009-9308$\mathrm{x}, 2009$.

Quintero, C. E., Gutiérrez-Boem, F. H., Befani, M. R., and Boschetti, N. G.: Effects of soil flooding on P transformations in soils of the Mesopotamia region, Argentina, J. Plant Nutr. Soil Sc., 170, 500-505, https://doi.org/10.1002/jpln.200625015, 2007.

Rakotoson, T., Amery, F., Rabeharisoa, L., and Smolders, E.: Soil flooding and rice straw addition can increase isotopic exchangeable phosphorus in P-deficient tropical soils, Soil Use Manage., 30, 189-197, https://doi.org/10.1111/sum.12120, 2014.

R Core Team: R: A language and environment for statistical computing. R Foundation for Statistical Computing, Vienna, Austria, 
available at: https://www.R-project.org/, last access: 7 September 2019.

Reed, S. C. and Wood, T. E.: Soil phosphorus cycling in tropical soils: An ultisol and oxisol perspective, in: Soil phosphorus, Taylor \& Francis, Oxfordshire, UK, 247-283, 2016.

Roy, E. D., Willig, E., Richards, P., Martinelli, L. A., Vazquez, F. F., Pegorini, L., Spera, S. A., and Porder, S.: Soil phosphorus sorption capacity after three decades of intensive fertilization in Mato Grosso, Brazil, Agriculture Ecosystems Environment, 249, 206-214, https://doi.org/10.1016/j.agee.2017.08.004, 2017.

Ryden, J. C. and Syers, J. K.: Origin of the labile phosphate pool in soils, Soil Sci., 123, 353-361, 1977.

Sallade, Y. E. and Sims, J. T.: Phosphorus transformations in the sediments of Delaware's agricultural drainageways: II. Effect of reducing conditions on phosphorus release, J. Environ. Qual., 26, 1579-1588, 1997.

Scatena, F. N.: An introduction to the physiography and history of the Bisley Experimental Watersheds in the Luquillo Mountains of Puerto Rico, US Department of Agriculture, Forest Service, Southern Forest Experiment Station, New Orleans, LA, 1989.

Scatena, F. N. and Lugo, A. E.: Geomorphology, disturbance, and the soil and vegetation of two subtropical wet steepland watersheds of Puerto Rico, Geomorphology, 13, 199-213, 1995.

Schuur, E. A. G., Chadwick, O. A., and Matson, P. A.: Carbon cycling and soil carbon storage in mesic to wet Hawaiian montane forests, Ecology, 82, 3182-3196, 2001.

Shenker, M., Seitelbach, S., Brand, S., Haim, A., and Litaor, M. I.: Redox reactions and phosphorus release in re-flooded soils of an altered wetland, European J. Soil Sci., 56, 515-525, 2005.

Silver, W. L., Scatena, F. N., Johnson, A. H., Siccama, T. G., and Sanchez, M. J.: Nutrient availability in a montane wet tropical forest: spatial patterns and methodological considerations, Plant Soil, 164, 129-145, 1994.

Silver, W. L., Lugo, A. E., and Keller, M.: Soil oxygen availability and biogeochemistry along rainfall and topographic gradients in upland wet tropical forest soils, Biogeochemistry, 44, 301-328, https://doi.org/10.1023/A:1006034126698, 1999.
Thompson, A. and Goyne, K. W.: Introduction to the sorption of chemical constituents in soils, Nature Education Knowledge, 4, 7, 2012.

Tiessen, H. and Moir, J. O.: Characterization of Available P by Sequential Extraction, in: Soil Sampling and Methods of Analysis, edited by: Carter, M. R., Lewis Publishers, Boca Raton, pp. 7586, 1993

Viollier, E., Inglett, P. W., Hunter, K., Roychoudhury, A. N., and Van Cappellen, P.: The ferrozine method revisited: Fe (II)/Fe (III) determination in natural waters, Appl. Geochem., 15, 785-790, 2000.

Vitousek, P. M. and Sanford Jr., R. L.: Nutrient cycling in moist tropical forest, Annu. Rev. Ecol. Syst., 17, 137-167, 1986.

Walpersdorf, E., Koch, C. B., Heiberg, L., O'Connell, D. W., Kjaergaard, C., and Hansen, H. C. B.: Does vivianite control phosphate solubility in anoxic meadow soils?, Geoderma, 193-194, 189199, https://doi.org/10.1016/j.geoderma.2012.10.003, 2013.

Weaver, P. L. and Murphy, P. G.: Forest structure and productivity in Puerto Rico's Luquillo Mountains, Biotropica, 22, 69-82, 1990.

Wieder, W. R., Cleveland, C. C., and Townsend, A. R.: Throughfall exclusion and leaf litter addition drive higher rates of soil nitrous oxide emissions from a lowland wet tropical forest, Global Change Biol., 17, 3195-3207, 2011.

Willett, I. R.: Causes and prediction of changes in extractable phosphorus during flooding, Soil Res., 27, 45-54, 1989.

Wilmoth, J. L., Moran, M. A., and Thompson, A.: Transient $\mathrm{O}_{2}$ pulses direct $\mathrm{Fe}$ crystallinity and $\mathrm{Fe}(\mathrm{III})$-reducer gene expression within a soil microbiome, Microbiome, 6, 189, https://doi.org/10.1186/s40168-018-0574-5, 2018.

Wisawapipat, W., Kheoruenromne, I., Suddhiprakarn, A., and Gilkes, R. J.: Phosphate sorption and desorption by Thai upland soils, Geoderma, 153, 408-415, https://doi.org/10.1016/j.geoderma.2009.09.005, 2009.

Zhang, Y. S., Lin, X. Y., and Werner, W.: The effect of soil flooding on the transformation of $\mathrm{Fe}$ oxides and the adsorption/desorption behavior of phosphate, J. Plant Nutr. Soil Sc., 166, 68-75, https://doi.org/10.1002/jpln.200390014, 2003. 